\title{
Correction to: The "Risser+" grade: a new grading system to classify skeletal maturity in idiopathic scoliosis
}

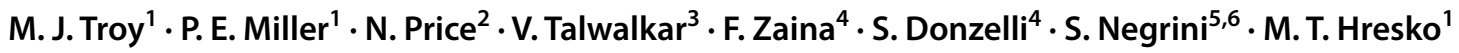

Published online: 6 February 2019

(c) Springer-Verlag GmbH Germany, part of Springer Nature 2019

Correction to: European Spine Journal https://doi.org/10.1007/s00586-018-5821-8

BrAIST data provided to the authors by Drs. Dolan and Weinstein at the University of Iowa. BrAIST was funded by the National Institute of Arthritis and Musculoskeletal and Skin Diseases (R21AR049587 and R01AR052113, to Dr. Weinstein), the Children's Miracle Network (to Dr. Weinstein), the Canadian Institutes of Health Research (FRN81050, to Dr. Wright), the Shriners Hospitals for Children (to Dr. Dobbs), the University of Rochester (to Dr. Sanders), and the Children's Mercy Hospital and Clinics (to Dr. Price). The content is solely the responsibility of the authors and does not necessarily represent the views of the sponsors or the BrAIST investigators.

Investigators:

Stuart L. Weinstein, MD and Lori A. Dolan, PhD, University of Iowa, Iowa City

James G. Wright, MD, Hospital for Sick Children

Matthew B. Dobbs, MD, Washington University of St. Louis and Shriner's Hospital for Children, St. Louis

James O. Sanders, MD, University of Rochester

Nigel J. Price, MD, Richard Schwend, MD, Children's Mercy Hospital, Kansas City

The original article can be found online at https://doi.org/10.1007/ s00586-018-5821-8.

\footnotetext{
M. T. Hresko

Timothy.Hresko@childrens.harvard.edu

1 Boston Children Hospital, Harvard Medical School, Boston, USA

2 Children's Mercy Hospital, Kansas City, USA

3 Shriners Hospital, Lexington, USA

4 ISICO - L'Istituto Scientifico Italiano Colonna Vertebrale, Milan, Italy

5 University of Brescia, Brescia, Italy

6 IRCCS Fondazione Don Carlo Gnocchi, Milan, Italy
}

Henry J. Iwinski, MD, Shriner's Hospital for Children, Lexington

Mark F. Abel, MD, University of Virginia

Oheneba Boachie-Adjei, MD, Daniel W. Green, MD, Hospital for Special Surgery

Jacques L. d'Astous, MD, Shriner's Hospital for Children, Salt Lake City

John B. Emans, MD, J. Timothy Hresko, MD, Children's Hospital of Boston

John M. Flynn, MD, Children's Hospital of Philadelphia

Joseph A. Gerardi, MD, and Matthew Halsey, MD, Children's Hospital of Central California

Munish C. Gupta, MD, Shriner's Hospital for Children, Northern California

Kim W. Hammerberg, MD, Peter Sturm, MD, Shriner's Hospital for Children, Chicago

Antony Kallur-Antony, MD, Elizabeth A. Szalay, MD, University of New Mexico

Walter F. Krengel, III, MD, Kit Song, MD, Seattle Children's Hospital

Charles T. Mehlman, DO, MPH, Cincinnati Children's Hospital

Jean A. Ouellet, MD, Shriner's Hospital for Children, Montreal

Christopher W. Reilly, MD, British Columbia Children's Hospital

Michael L. Schmitz, MD, Children's Orthopaedics of Atlanta

Suken A. Shah, MD, Alfred I. duPont Hospital for Children

W. Timothy Ward, MD, Children's Hospital of Pittsburgh 